\title{
ANALISIS KEUNTUNGAN INDUSTRI RUMAH TANGGA ROTI ANUGERAH DI PANCORAN MAS, KOTA DEPOK
}

\author{
Agus $^{1}$ \\ Rahmad Faisal ${ }^{2}$ \\ Raliono $^{3}$ \\ ${ }^{1,2,3}$ Program Studi Manajemen STIE Fajar, Depok \\ Email: $\underline{\text { rahmadfaisal79@gmail.com }}^{2}$
}

\begin{abstract}
ABSTRAK
Penelitian ini bertujuan untuk menganalisis struktur biaya dan keuntungan pada industri rumah tangga Roti Anugerah di Pancoran Mas, Kota Depok. Data yang digunakan adalah data primer yang diperoleh dari wawancara langsung dengan berpedoman pada kuesioner. Analisis data dilakukan dengan menggunakan metode analisis keuntungan dan struktur biaya produksi dengan pendekatan jangka pendek. Hasil penelitian menunjukkan bahwa: (1) besarnya biaya total yang dikeluarkan oleh industri rumah tangga Roti Anugerah adalah Rp772.989.250,00 per tahun dengan 93,29\% di antaranya merupakan biaya variabel yang berasal dari pembelian bahan-bahan produksi, yaitu sebesar Rp721.160.000,00 dan $6,71 \%$ sisanya merupakan biaya tetap yang terdiri dari biaya tenaga kerja, administrasi dan penyusutan aset, yakni sebesar Rp51.829.250,00; dan (2) besarnya keuntungan yang diperoleh produsen Roti Anugerah adalah Rp1.852.850.750,00 per tahun.
\end{abstract}

Kata kunci: Biaya, keuntungan, biaya variabel, biaya tetap

\section{ABSTRACT}

This study aims to analyze the cost and profit structure at Anugerah Bakery home industry in Pancoran Mas, Depok City. The data used are primary data obtained from direct interviews based on the questionnaire. Data analysis was performed using profit and production cost structure analysis method with short-term approach. The results of the study showed that: (1) the total cost incurred by Anugerah Bakery home industry is Rp772.989.250,00 per year with 93,29\% of which are variable costs which comes from the purchase of production materials, namely in the amount of Rp721.160.000,00 and the remaining $6,71 \%$ are fixed costs consisting of costs of labor, administration and depreciation of assets, namely in the amount of Rp51.829.250,00; and (2) the amount of profits obtained by Anugerah bread producer is Rp1.852.850.750,00 per year.

Keywords: Cost, profit, variable cost, fixed cost

\section{PENDAHULUAN}

Kota Depok yang merupakan daerah penyangga Ibukota yang menjadi tujuan urbanisasi dari berbagai daerah, baik dari Pulau Jawa maupun luar Pulau Jawa. Dengan wilayah seluas 200,29 km², jumlah penduduk Kota Depok di tahun 2016 mencapai 2.179.813 jiwa dengan 1.098.473 jiwa di antaranya merupakan penduduk laki-laki dan 1.081.340 jiwa lainnya merupakan penduduk perempuan. Kepadatan penduduk di kota tersebut juga tergolong sangat padat, yaitu dengan sebaran sebanyak $5.916 \mathrm{jiwa} / \mathrm{km}^{2} \mathrm{di}$ 
Kecamatan Sawangan dan $16.788 \mathrm{jiwa} / \mathrm{km}^{2}$ di Kecamatan Sukmajaya, sehingga total ratarata kepadatannya mencapai $10.883 \mathrm{jiwa} / \mathrm{km}^{2}$ (BPS Kota Depok, 2017).

Jumlah penduduk Kota Depok yang tinggi telah membuka peluang bisnis yang besar bagi wirausahawan. Salah satu peluang bisnis yang memiliki prospek yang baik di kota tersebut adalah bisnis produksi makanan atau kuliner. Bisnis roti merupakan salah satu bisnis produksi makanan atau kuliner yang tidak pernah mengenal musim dan cukup disukai oleh masyarakat Indonesia, termasuk masyarakat di Kota Depok. Salah satu bisnis produksi roti yang sedang tumbuh dan berkembang di Kota Depok adalah industri rumah tangga Roti Anugerah yang telah berdiri sejak tahun 2012. Dalam kegiatan operasionalnya, industri rumah tangga tersebut rutin memproduksi roti dengan empat varian rasa, yaitu cokelat, keju, kacang, dan nanas.

Tabel di bawah ini menunjukkan jumlah unit yang diproduksi oleh industri rumah tangga Roti Anugerah per minggunya untuk setiap jenis varian rasa.

Tabel 1. Jenis dan Jumlah Produksi Roti Anugerah per Minggu

\begin{tabular}{|c|l|c|}
\hline No. & \multicolumn{1}{|c|}{ Jenis Roti } & $\begin{array}{c}\text { Jumlah Produksi/ } \\
\text { Minggu (Unit) }\end{array}$ \\
\hline 1. & Rasa Cokelat & 15.600 \\
\hline 2. & Rasa Keju & 10.400 \\
\hline 3. & Rasa Kacang & 10.400 \\
\hline 4. & Rasa Nanas & 10.400 \\
\hline
\end{tabular}

(Sumber: Wawancara dengan pemilik, 7 Juli 2018)

Berdasarkan tabel di atas, setiap minggunya, industri rumah tangga Roti Anugerah memproduksi tidak kurang dari 10.000 unit untuk setiap jenis varian rasanya. Hal tersebut mencerminkan cukup stabilnya volume operasi dari home industry tersebut.

Meskipun industri rumah tangga Roti Anugerah telah mampu beroperasi secara stabil dan berkelanjutan, muncul berbagai tantangan yang harus dihadapinya seiring dengan berjalannya waktu dan berkembangnya usaha tersebut. Tantangan tersebut biasanya berkaitan erat dengan bahan baku dan kemunculan usaha yang sama. Selain berisiko kehilangan pasar aktual dan potensial, kemunculan usaha yang sama juga dapat melemahkan daya tawar terhadap supplier, sehingga home industry yang bersangkutan berisiko mengalami kekurangan bahan baku ataupun pembengkakan biaya bahan baku akibat tingginya persaingan untuk memperoleh bahan baku tersebut. Akibatnya, profitabilitas home industry tersebut berpotensi mengalami penurunan. Oleh karena itu, tantangan-tantangan tersebut perlu diatasi sedemikian rupa dan diantisipasi dampakdampaknya agar tidak mengganggu keberlangsungan usaha dalam jangka panjang.

Dalam rangka mengantisipasi dan mengidentifikasi dampak-dampak dari berbagai 
tantangan yang dihadapi oleh industri rumah tangga yang bergerak di bidang produksi makanan, perlu dilakukan analisis terhadap struktur biaya dan keuntungan pada industri rumah tangga yang bergerak di bidang tersebut yang dalam penelitian ini direpresentasikan oleh industri rumah tangga Roti Anugerah.

\section{TINJAUAN PUSTAKA}

\section{Biaya Produksi}

Menurut Simamora (2006:36), biaya adalah kas dan setaranya yang dikorbankan untuk memperoleh produk yang diekspektasikan dapat memberi manfaat bagi suatu organisasi tertentu, baik di saat ini maupun di masa mendatang. Bustami dan Nurlela (2013:7) mendefinisikan biaya sebagai pengorbanan sumber ekonomis yang telah terjadi ataupun akan terjadi dan diukur dalam satuan uang tertentu untuk mencapai suatu tujuan.

Menurut Carter (2009:43), biaya dapat dibedakan menjadi tiga jenis, yaitu sebagai berikut.

1. Biaya variabel, yakni biaya yang besarnya berubah secara proporsional mengikuti perubahan aktivitas-aktivitas dalam rentang yang relevan.

2. Biaya tetap, yakni biaya yang totalnya bersifat konstan dalam rentang yang relevan.

3. Biaya semivariabel, yakni biaya yang memiliki unsur biaya tetap dan biaya variabel.

Biaya yang dipergunakan dalam suatu proses produksi dan terdiri dari biaya bahan baku langsung, tenaga kerja langsung dan overhead pabrik diartikan sebagai biaya produksi (Bustami dan Nurlela, 2013:12). Menurut Horngren, et al. (2008:51), biaya produksi merupakan biaya yang dibebankan atas suatu produk yang digunakan untuk mencapai suatu tujuan tertentu.

\section{Pendapatan}

Berdasarkan PSAK No. 23, pendapatan adalah arus masuk bruto dari manfaat ekonomi yang timbul dari aktivitas normal suatu perusahaan selama suatu periode bila arus masuk itu mengakibatkan kenaikan ekuitas, yang tidak berasal dari kontribusi penanam modal (IAI, 2014). Pendapatan merupakan sejumlah balas jasa yang diterima oleh masyarakat untuk suatu periode waktu tertentu atas faktor-faktor produksi yang disumbangkan dalam keikutsertaannya pada pembentukan suatu produk nasional (Suparyanto, 2014).

Dalam PSAK No. 23 disebutkan bahwa pendapatan harus diukur dengan nilai 
wajar dari imbalan yang diterima dimana jumlah pendapatan yang timbul dari suatu transaksi akan ditentukan oleh persetujuan antara perusahaan dan pembeli/pengguna dari aset yang dimaksud. Jumlah tersebut diukur dengan nilai wajar dari imbalan yang diterima atau yang dapat diterima perusahaan dikurangi dengan jumlah diskon dagang dan rabat volume yang diperbolehkan oleh perusahaan yang bersangkutan (IAI, 2014).

Menurut Sunuharjo (2009) dalam Suparyanto (2014), pendapatan dapat dibedakan ke dalam tiga kategori, yaitu sebagai berikut.

1. Pendapatan berupa uang, yakni segala penghasilan dalam bentuk uang yang bersifat reguler dan biasanya diterima sebagai suatu balas jasa atau kontra prestasi.

2. Pendapatan berupa barang, yakni segala pendapatan yang bersifat reguler dan biasa yang selalu diterima dalam bentuk barang dan jasa.

3. Pendapatan yang bukan merupakan pendapatan, yakni segala penerimaan yang bersifat transfer redistributive dan cenderng memberikan perubahan dalam kondisi keuangan suatu rumah tangga.

\section{Keuntungan}

Hanafi (2010:32) mendefinisikan laba sebagai ukuran atas keseluruhan prestasi perusahaan yang dirumuskan sebagai selisih antara penjualan yang dihasilkan oleh perusahaan tersebut dan biaya yang dikeluarkannya. Menurut Harahap (2009), laba adalah kelebihan dari penghasilan suatu perusahaan di atas biaya yang dikeluarkannya selama suatu periode akuntansi tertentu. Suwardjono (2008) mengartikan laba sebagai suatu imbalan atas upaya yang dilakukan oleh perusahaan dalam menghasilkan barang dan jasa.

Kasmir (2013:303) membedakan laba menjadi dua jenis, yaitu sebagai berikut.

1. Laba kotor (gross profit), yakni laba yang diperoleh suatu perusahaan sebelum dikurangi oleh biaya-biaya yang membebaninya.

2. Laba bersih (net profit), yakni laba yang diperoleh suatu perusahaan setelah dikurangi oleh biaya-biaya yang membebaninya dalam susatu periode tertentu, termasuk pajak.

\section{METODOLOGI PENELITIAN}

Penelitian ini menggunakan studi kasus pada sebuah perusahaan di industri rumah tangga penghasil roti, yaitu industri rumah tangga Roti Anugerah yang terletak di Rawa Denok, Rangkapan Jaya, Pancoran Mas Kota, Depok. Penelitian berlangsung selama tiga, bulan, yaitu sejak Juni hingga Agustus 2018. Data primer yang diperoleh dari wawancara langsung dengan berpedoman pada kuesioner digunakan sebagai data penelitian. 
Dalam penelitian ini, dilakukan dua macam analisis, yaitu analisis deskriptif dan kuantitatif. Analisis deskriptif dilakukan terutama untuk mendapatkan pemahaman tentang gambaran umum perusahaan serta penjelasan atas hasil-hasil yang didapatkan dari analisis kuantitatif. Analisis kuantitatif itu sendiri dilakukan untuk menganalisis struktur biaya produksi dan keuntungan. Dalam penelitian ini, struktur biaya produksi dianalisis dengan menggunakan pendekatan jangka pendek yang menyatakan bahwa total biaya produksi terdiri dari total biaya tetap dan total biaya variabel. Selain itu, juga dilakukan penentuan terhadap proporsi biaya dari beberapa input penting, seperti penyusutan bangunan dan mesin serta peralatan produksi, bahan-bahan produksi, tenaga kerja, dan sebagainya.

\section{HASIL DAN PEMBAHASAN}

\section{Biaya Produksi}

Dalam jangka pendek, total biaya produksi merupakan penjumlahan antara total biaya tetap atau Total Fixed Cost (TFC) dan total biaya variabel atau Total Variable Cost (TVC). Industri rumah tangga Roti Anugerah mengalokasikan biaya tetapnya untuk mendanai investasi dan tenaga kerja administrasi. Investasi yang dilakukan oleh industri rumah tangga Roti Anugerah antara lain membeli tanah tempat usaha, mendirikan bangunan pabrik, serta membeli mesin produksi, peralatan produksi dan sarana transportasi.

Berdasarkan harga atau nilai pada saat pembelian atau pembangunannya, total investasi industri rumah tangga Roti Anugerah disajikan dalam tabel berikut.

Tabel 2. Total Investasi Industri Rumah Tangga Roti Anugerah

\begin{tabular}{|c|c|c|c|c|c|c|}
\hline \multirow[b]{2}{*}{ No. } & \multirow[b]{2}{*}{ Jenis Investasi } & \multirow[b]{2}{*}{ Satuan } & \multirow[b]{2}{*}{ Kuantitas } & \multirow{2}{*}{$\begin{array}{c}\text { Harga/Satuan } \\
\text { (Rp) }\end{array}$} & \multicolumn{2}{|c|}{ Jumlah } \\
\hline & & & & & Nilai (Rp) & $\begin{array}{c}\text { Persentase } \\
(\%)\end{array}$ \\
\hline 1. & Tanah & $\mathrm{m}^{2}$ & 100 & 1.000 .000 & 100.000 .000 & 25,55 \\
\hline 2. & Bangunan & $\mathrm{m}^{2}$ & 100 & 500.000 & 50.000 .000 & 12,77 \\
\hline 3. & Mixer & Unit & 1 & 6.000 .000 & 6.000 .000 & 1,53 \\
\hline 4. & Mesin Pembagi & Unit & 1 & 5.000 .000 & 5.000 .000 & 1,28 \\
\hline 5. & Mesin Packing & Unit & 1 & 50.000 .000 & 50.000 .000 & 12,77 \\
\hline 6. & Mesin Oven & Unit & 2 & 1.200 .000 & 2.400 .000 & 0,61 \\
\hline 7. & Loyang & Unit & 5 & 5.000 .000 & 25.000 .000 & 6,39 \\
\hline 8. & Timbangan & Unit & 1 & 750.000 & 750.000 & 0,19 \\
\hline 9. & Tabung gas $12 \mathrm{~kg}$ & Unit & 2 & 400.000 & 800.000 & 0,20 \\
\hline 10. & Meja & Unit & 2 & 250.000 & 500.000 & 0,13 \\
\hline 11. & Box wadah roti & Unit & 200 & 30.000 & 6.000 .000 & 1,53 \\
\hline 12. & Mobil pick up & Unit & 1 & 145.000 .000 & 145.000 .000 & 37,04 \\
\hline \multicolumn{5}{|c|}{ Total Investasi } & 391.450 .000 & 100,00 \\
\hline
\end{tabular}

(Sumber: Data Industri Rumah Tangga Roti Anugerah, 2018) 
Berdasarkan tabel di atas, besarnya total investasi industri rumah tangga Roti Anugerah adalah Rp391.450.000,00. Biaya terbesar diperuntukkan bagi pembelian alat transportasi berupa mobil pick up, yaitu dengan nilai sebesar Rp145.000.000,00 atau 37,04\% dari total investasi. Pos biaya tetap terbesar kedua dan ketiga diperuntukkan bagi pembelian tanah, yaitu sebesar Rp100.000.000,00 atau 25,55\% dari total investasi, serta pendirian bangunan pabrik dan pembelian mesin packing yang masing-masing sebesar Rp50.000.000,00 atau $12,77 \%$ dari total investasi.

Berdasarkan besarnya investasi sebagaimana yang disajikan dalam tabel 2 di atas, nilai penyusutan dari setiap investasi tersebut disajikan dalam tabel sebagai berikut.

Tabel 3. Nilai Penyusutan Investasi Industri Rumah Tangga Roti Anugerah

\begin{tabular}{|c|l|r|r|}
\hline \multirow{2}{*}{ No. } & \multirow{2}{*}{ Jenis Investasi } & \multicolumn{2}{|c|}{ Penyusutan/Tahun } \\
\cline { 3 - 4 } & & Nilai (Rp) & Persentase (\%) \\
\hline 1. & Tanah & & \\
\hline 2. & Bangunan & 1.875 .000 & 6,74 \\
\hline 3. & Mixer & 1.140 .000 & 4,10 \\
\hline 4. & Mesin pembagi & 950.000 & 3,41 \\
\hline 5. & Mesin packing & 4.750 .000 & 17,07 \\
\hline 6. & Mesin oven & 468.000 & 1,68 \\
\hline 7. & Loyang & 4.950 .000 & 17,79 \\
\hline 8. & Timbangan & 71.250 & 0,26 \\
\hline 9. & Tabung gas $12 \mathrm{~kg}$ & 0 & 0,00 \\
\hline 10. & Meja & 100.000 & 0,36 \\
\hline 11. & Box wadah roti & 1.200 .000 & 4,31 \\
\hline 12. & Mobil pick up & 12.325 .000 & 44,29 \\
\hline \multicolumn{2}{|c|}{ Jumlah } & $\mathbf{2 7 . 8 2 9 . 2 5 0}$ & $\mathbf{1 0 0 , 0 0}$ \\
\hline
\end{tabular}

(Sumber: Data Industri Rumah Tangga Roti Anugerah, 2018)

Tabel di atas menunjukkan bahwa besarnya biaya penyusutan yang dikeluarkan oleh industri rumah tangga Roti Anugerah adalah Rp27.829.250,00 per tahun atau setara dengan Rp579.776,00 per minggu. Nilai tersebut kemudian dijumlahkan dengan besarnya biaya tetap yang dialokasikan untuk tenaga kerja administrasi yang bersangkutan, seperti yang terlihat pada tabel berikut.

Tabel 4. Total Biaya Tetap Industri Rumah Tangga Roti Anugerah

\begin{tabular}{|c|c|r|r|}
\hline \multirow{2}{*}{ No. } & \multirow{2}{*}{ Jenis Biaya Tetap } & \multicolumn{2}{|c|}{ Biaya per Tahun } \\
\cline { 3 - 4 } & & Jumlah (Rp) & Persentase (\%) \\
\hline 1. & Tenaga kerja administrasi & 24.000 .000 & 46,31 \\
\hline 2. & Penyusutan & 27.829 .250 & 53,69 \\
\hline \multicolumn{2}{|c|}{ Jumlah } & $\mathbf{5 1 . 8 2 9 . 2 5 0}$ & $\mathbf{1 0 0 , 0 0}$ \\
\hline
\end{tabular}

(Sumber: Data Industri Rumah Tangga Roti Anugerah, 2018) 
Berdasarkan tabel di atas, besarnya total biaya tetap per tahun industri rumah tangga Roti Anugerah setelah ditambah dengan biaya tenaga kerja administrasinya adalah Rp51.829.250,00 per tahun atau setara dengan Rp1.079.776,00 per minggu

Selain biaya tetap, perusahaan juga mengeluarkan biaya atas penggunaan input variabel. Biaya input variabel yang digunakan dalam industri rumah tangga Roti Anugerah antara lain terdiri dari biaya bahan produksi, energi, dan tenaga kerja produksi. Berikut ini disajikan tabel biaya bahan produksi industri rumah tangga Roti Anugerah.

Tabel 5. Biaya Bahan Produksi Industri Rumah Tangga Roti Anugerah

\begin{tabular}{|c|c|c|c|c|c|c|c|}
\hline \multirow{2}{*}{ No. } & \multirow{2}{*}{ Jenis Bahan } & \multirow{2}{*}{ Satuan } & \multirow{2}{*}{ Jumlah } & \multirow{2}{*}{$\begin{array}{c}\text { Harga/ } \\
\text { Satuan } \\
\text { (Rp) }\end{array}$} & \multirow{2}{*}{$\begin{array}{c}\text { Nilai/ } \\
\text { Minggu } \\
(\mathbf{R p})\end{array}$} & \multicolumn{2}{|c|}{$\begin{array}{c}\text { Biaya Bahan } \\
\text { Produksi per Tahun }\end{array}$} \\
\hline & & & & & & $\begin{array}{c}\text { Jumlah } \\
\text { (Rp) }\end{array}$ & $\%$ \\
\hline 1. & Terigu & $\mathrm{kg}$ & 780 & 6.000 & 4.680 .000 & 187.200 .000 & 34,98 \\
\hline 2. & Gula pasir & $\mathrm{kg}$ & 210 & 11.000 & 2.310 .000 & 92.400 .000 & 17,26 \\
\hline 3. & Mentega & $\mathrm{kg}$ & 108 & 10.000 & 1.080 .000 & 43.200 .000 & 8,07 \\
\hline 4. & Ragi & $\mathrm{kg}$ & 18 & 20.000 & 360.000 & 14.400 .000 & 2,69 \\
\hline 5. & Selai kacang & $\mathrm{kg}$ & 40 & 10.000 & 400.000 & 16.000 .000 & 2,99 \\
\hline 6. & Selai cokelat & $\mathrm{kg}$ & 60 & 10.000 & 600.000 & 24.000 .000 & 4,48 \\
\hline 7. & Selai keju & $\mathrm{kg}$ & 10 & 10.000 & 100.000 & 4.000 .000 & 0,75 \\
\hline 8. & Selai nanas & $\mathrm{kg}$ & 10 & 10.000 & 100.000 & 4.000 .000 & 0,75 \\
\hline 9. & Plastik pembungkus & Roll & 10 & 375.000 & 3.750 .000 & 150.000 .000 & 28,03 \\
\hline \multicolumn{5}{|c|}{ Total Biaya Bahan Produksi } & 13.380 .000 & 535.200 .000 & 100,00 \\
\hline
\end{tabular}

(Sumber: Data Industri Rumah Tangga Roti Anugerah, 2018)

Berdasarkan tabel di atas, besarnya biaya bahan produksi yang dikeluarkan oleh industri rumah tangga Roti Anugerah adalah Rp13.380.000 per minggu atau Rp535.200.000,00 per tahun.

Biaya variabel lainnya yang dikeluarkan oleh industri rumah tangga Roti Anugerah adalah biaya energi. Jenis energi yang dibutuhkan tersebut antara lain gas, listrik dan bahan bakar minyak. Besarnya biaya energi yang dikeluarkan oleh industri rumah tangga Roti Anugerah dapat dilihat pada tabel berikut.

Tabel 6. Biaya Energi Industri Rumah Tangga Roti Anugerah

\begin{tabular}{|c|c|c|c|c|c|c|c|}
\hline \multirow{2}{*}{ No. } & \multirow{2}{*}{ Jenis Energi } & \multirow{2}{*}{ Satuan } & \multirow{2}{*}{ Jumlah } & \multirow{2}{*}{$\begin{array}{l}\text { Harga/ } \\
\text { Satuan } \\
\text { (Rp) }\end{array}$} & \multirow{2}{*}{$\begin{array}{c}\text { Biaya/ } \\
\text { Minggu } \\
(\mathbf{R p})\end{array}$} & \multicolumn{2}{|c|}{$\begin{array}{l}\text { Biaya Energi } \\
\text { per Tahun }\end{array}$} \\
\hline & & & & & & $\begin{array}{c}\text { Jumlah } \\
\text { (Rp) }\end{array}$ & $\%$ \\
\hline 1. & Bahan bakar gas $12 \mathrm{~kg}$ & Tabung & 1 & 120.000 & 120.000 & 4.800 .000 & 26,73 \\
\hline 2. & Listrik & $\mathrm{Rp} / \mathrm{mg}$ & 1 & 200.000 & 200.000 & 8.000 .000 & 44,54 \\
\hline 3. & Bahan bakar minyak & Liter & 20 & 6.450 & 129.000 & 5.160 .000 & 28,73 \\
\hline \multicolumn{5}{|c|}{ Jumlah Total Biaya Energi } & 449.000 & 17.960 .000 & 100,00 \\
\hline
\end{tabular}

(Sumber: Data Industri Rumah Tangga Roti Anugerah, 2018)

Berdasarkan tabel di atas, besarnya biaya energi yang dikeluarkan oleh industri rumah tangga Roti Anugerah adalah Rp449.000,00 per minggu atau Rp17.960.000,00 per tahun. 
Biaya variabel lainnya yang dikeluarkan oleh industri rumah tangga Roti Anugerah adalah biaya tenaga kerja produksi. Dalam hal ini, industri rumah tangga Roti Anugerah memiliki 10 orang tenaga kerja produksi dengan upah harian sebesar Rp70.000,00 per hari, sehingga besarnya total biaya tenaga kerja produksi industri rumah tangga Roti Anugerah adalah Rp4.200.000,00 per minggu atau Rp168.000.000,00 per tahun.

Berdasarkan biaya bahan produksi, energi, dan tenaga kerja produksi, besarnya total biaya variabel industri rumah tangga Roti Anugerah dapat dilihat pada tabel berikut.

Tabel 7. Biaya Variabel Industri Rumah Tangga Roti Anugerah

\begin{tabular}{|c|l|r|r|}
\hline \multirow{2}{*}{ No. } & \multirow{2}{*}{ Jenis Biaya Variabel } & \multicolumn{2}{|c|}{ Biaya per Tahun } \\
\cline { 3 - 4 } & & Jumlah (Rp) & Persentase (\%) \\
\hline 1. & Bahan-bahan produksi & 535.200 .000 & 74,21 \\
\hline 2. & Energi & 17.960 .000 & 2,49 \\
\hline 3. & Tenaga kerja produksi & 168.000 .000 & 23,30 \\
\hline \multicolumn{2}{|c|}{ Jumlah } & $\mathbf{7 2 1 . 1 6 0 . 0 0 0}$ & $\mathbf{1 0 0 , 0 0}$ \\
\hline
\end{tabular}

(Sumber: Data Industri Rumah Tangga Roti Anugerah, 2018)

Berdasarkan tabel di atas, besarnya total biaya variabel industri rumah tangga Roti Anugerah adalah Rp721.160.000,00 per tahun atau Rp15.024.167,00 per minggu. Kontribusi terbesar berasal dari pembelian bahan-bahan produksi, yaitu dengan biaya sebesar Rp535.200.000,00 atau setara dengan 74,21\% dari total biaya variabel per tahun. Pengeluaran untuk tenaga kerja produksi menempati urutan kedua, yaitu dengan biaya sebesar Rp168.000.000,00 atau setara dengan 23,30\% dari total biaya variabel per tahun. Di urutan terakhir, penggunaan energi menimbulkan pengeluaran biaya sebesar Rp17.960.000,00 per tahun atau setara dengan 2,49\% dari total biaya variabel per tahun.

Berdasarkan total biaya tetap per tahun sebagaimana yang tercantum dalam tabel 4 dan total biaya variabel per tahun sebagaimana yang tercantum dalam tabel 7 , total biaya atau Total Cost (TC) per tahun dari industri rumah tangga Roti Anugerah dapat dihitung sebagai berikut.

TC

$$
=\mathrm{TFC}+\mathrm{TVC}
$$

TC per Tahun $=$ TFC per tahun + TVC per tahun

$$
\begin{aligned}
& =\operatorname{Rp} 51 \cdot 829 \cdot 250,00+\operatorname{Rp} 721 \cdot 160.000,00 \\
& =\operatorname{Rp} 772,989 \cdot 250,00
\end{aligned}
$$

Berdasarkan hasil perhitungan di atas, total biaya yang dikeluarkan oleh industri rumah tangga Roti Anugerah per tahun adalah Rp772.989.250,00 atau Rp16.103.943,00 per minggu. Kontribusi dari setiap jenis biaya dapat dilihat pada tabel berikut ini. 
Tabel 8. Total Biaya Industri Rumah Tangga Roti Anugerah

\begin{tabular}{|c|c|c|r|}
\hline \multirow{2}{*}{ No. } & \multirow{2}{*}{ Jenis Biaya } & \multicolumn{2}{|c|}{ Biaya per Tahun } \\
\cline { 3 - 4 } & & Jumlah (Rp) & Persentase (\%) \\
\hline 1. & Total biaya tetap & 51.829 .250 & 6,71 \\
\hline 2. & Total biaya variabel & 721.160 .000 & 93,29 \\
\hline \multicolumn{2}{|c|}{ Total Biaya } & $\mathbf{7 7 2 . 9 8 9 . 2 5 0}$ & $\mathbf{1 0 0 , 0 0}$ \\
\hline
\end{tabular}

(Sumber: Data Industri Rumah Tangga Roti Anugerah, 2018)

Berdasarkan tabel di atas, pos biaya terbesar berasal dari total biaya variabel per tahun, yaitu sebesar Rp721.160.000,00 atau setara dengan 93,29\% dari total biaya. Sementara itu, $6,71 \%$ sisanya berasal dari total biaya tetap, yaitu sebesar Rp51.829.250,00.

\section{Keuntungan Bisnis}

Roti yang diproduksi oleh industri rumah tangga Roti Anugerah memiliki empat varian rasa, yaitu cokelat, keju, kacang dan nanas, sehingga pendapatan usahanya pun berasal dari penjualan keempat jenis roti tersebut dengan harga jual sebesar Rp1.500,00 per satuan roti. Total pendapatan usaha yang diperoleh industri rumah tangga Roti Anugerah dari penjualan keempat jenis roti tersebut disajikan dalam tabel sebagai berikut.

Tabel 9. Pendapatan Usaha Industri Rumah Tangga Roti Anugerah

\begin{tabular}{|c|c|c|c|c|c|}
\hline \multirow{2}{*}{ No. } & \multirow{2}{*}{ Jenis Roti } & \multirow{2}{*}{$\begin{array}{c}\text { Kuantitas/ } \\
\text { Minggu }\end{array}$} & \multirow{2}{*}{$\begin{array}{c}\text { Harga/ } \\
\text { Satuan } \\
(\mathbf{R p})\end{array}$} & \multicolumn{2}{|c|}{ Pendapatan Usaha (Rp) } \\
\hline & & & & Per Minggu & Per Tahun \\
\hline 1. & Roti Cokelat & 14.664 & 1.500 & 21.996 .000 & 879.840 .000 \\
\hline 2. & Roti Keju & 9.672 & 1.500 & 14.508 .000 & 580.320 .000 \\
\hline 3. & Roti Kacang & 9.568 & 1.500 & 14.352 .000 & 574.080 .000 \\
\hline 4. & Roti Nanas & 9.360 & 1.500 & 14.040 .000 & 561.600 .000 \\
\hline \multicolumn{2}{|c|}{ Jumlah Penjualan } & 43.264 & - & 64.896.000 & 2.595.840.000 \\
\hline
\end{tabular}

(Sumber: Data Industri Rumah Tangga Roti Anugerah, 2018)

Berdasarkan tabel di atas, industri rumah tangga Roti Anugerah mampu menjual sebanyak 43.264 roti dengan berbagai varian rasa di setiap minggunya. Volume penjualan tersebut lebih kecil daripada volume produksinya yang mampu mencapai 46.800 roti per minggu sebagaimana yang tercantum pada tabel 1. Hal tersebut menunjukkan bahwa tidak seluruh roti yang diproduksi oleh industri rumah tangga Roti Anugerah dapat habis terjual. Dalam satu minggu, terdapat sekitar 6-10\% roti yang tidak terjual dan harus dibuang sebagai limbah karena sudah kadaluwarsa. Setiap minggunya, industri rumah tangga Roti Anugerah mampu menghasilkan pendapatan usaha sebesar Rp64.896.000,00 atau setara dengan Rp2.595.840.000,00 per tahun dari roti yang dijualnya.

Keuntungan usaha industri rumah tangga Roti Anugerah dapat dihitung dengan menggunakan rumus sebagai berikut. 


$$
\boldsymbol{\pi}=\mathbf{T R}-(\mathbf{T F C}+\mathbf{T V C})
$$

Keterangan:

$\pi=$ Pendapatan atau keuntungan usaha per minggu atau per tahun $(\mathrm{Rp})$

$\mathrm{TR}=$ Penerimaan usaha per minggu atau per tahun $(\mathrm{Rp})$

TFC = Total Fixed Cost, yaitu total biaya penyusutan ditambah biaya tenaga kerja administrasi per minggu atau per tahun (Rp)

TVC = Total Variable Cost, yaitu total biaya penggunaan bahan-bahan produksi, energi, dan tenaga kerja produksi per minggu atau per tahun (Rp)

Dengan menggunakan rumus tersebut, maka keuntungan yang diperoleh industri rumah tangga Roti Anugerah dapat dihitung sebagai berikut.

Keuntungan dalam satu minggu:

$$
\begin{aligned}
\pi \quad & =\operatorname{Rp} 64.896 .000-\operatorname{Rp} 16.103 .943 \\
& =\operatorname{Rp} 48.792 .057
\end{aligned}
$$

Keuntungan dalam satu tahun:

$$
\begin{aligned}
\pi \quad & =\mathrm{Rp} 2.595 .840 .000-\mathrm{Rp} 742.989 .250 \\
& =\mathrm{Rp} 1.852 .850 .750
\end{aligned}
$$

Uraian perhitungan keuntungan industri rumah tangga Roti Anugerah disajikan pada tabel sebagai berikut.

\section{Tabel 10. Keuntungan Industri Rumah Tangga Roti Anugerah}

\begin{tabular}{|c|c|r|r|}
\hline \multirow{2}{*}{ No. } & \multirow{2}{*}{ Uraian } & \multicolumn{2}{|c|}{ Nilai (Rp) } \\
\cline { 3 - 4 } & & \multicolumn{1}{c|}{ Per Minggu } & \multicolumn{1}{c|}{ Per Tahun } \\
\hline 1. & Nilai penjualan & 64.896 .000 & 2.595 .840 .000 \\
\hline 2. & Biaya total & 16.103 .943 & 772.989 .250 \\
\hline \multicolumn{2}{|c|}{ Keuntungan } & $\mathbf{4 8 . 7 9 2 . 0 5 7}$ & $\mathbf{1 . 8 2 2 . 8 5 0 . 7 5 0}$ \\
\hline
\end{tabular}

(Sumber: Data Industri Rumah Tangga Roti Anugerah, 2018)

Berdasarkan perhitungan dan tabel di atas, industri rumah tangga Roti Anugerah berada dalam kondisi yang menguntungkan karena mampu menghasilkan keuntungan sebesar Rp48.792.057,00 per minggu atau Rp1.852.850.750,00 per tahun.

\section{KESIMPULAN DAN SARAN}

\section{Kesimpulan}

Berdasarkan hasil penelitian ini, dapat disimpulkan hal-hal sebagai berikut.

1. Besarnya biaya total yang dikeluarkan oleh industri rumah tangga Roti Anugerah adalah Rp772.989.250,00 per tahun atau Rp16.103.943 per minggu dengan 93,29\% di 
antaranya merupakan biaya variabel yang berasal dari pembelian bahan-bahan produksi, yaitu sebesar Rp721.160.000,00 per tahun atau dan 6,71\% sisanya merupakan biaya tetap yang terdiri dari biaya tenaga kerja, administrasi dan penyusutan aset, yakni sebesar Rp51.829.250,00;

2. Besarnya keuntungan yang diperoleh industri rumah tangga Roti Anugerah adalah Rp1.852.850.750,00 per tahun atau Rp48.792.057 per minggu.

\section{Saran}

Berdasarkan kesimpulan di atas, industri rumah tangga Roti Anugerah harus meningkatkan volume penjualannya agar dapat sebanding dengan volume produksinya, sehingga dapat mengurangi inefisiensi produksi. Oleh karena itu, perusahaan perlu memperluas market usaha, melakukan diversifikasi produk, baik dari segi varian rasa maupun bentuk produk, atau dengan melakukan perhitungan optimasi produksi.

\section{DAFTAR PUSTAKA}

BPS Kota Depok. 2017. Kota Depok dalam Angka 2017. BPS Kota Depok. Depok.

BPS Kota Depok. 2017. Produk Domestik Regional Bruto Kota Depok Menurut Lapangan Usaha Tahun 2012-2016. BPS Kota Depok. Depok.

Bustami, B. dan Nurlela. 2013. Akuntansi Biaya. Edisi Keempat. Mitra Wacana Media. Jakarta.

Carter, W.K. Cost Accounting. $14^{\text {th }}$ Edition. Terjemahan Krista. 2009. Akuntansi Biaya. Edisi 14. Salemba Empat. Jakarta.

Hanafi, M.M. 2010. Manajemen Keuangan. BPFE. Yogyakarta.

Harahap, S.S. 2009. Analisis Kritis atas Laporan Keuangan. RajaGrafindo Persada. Jakarta.

Horngren, C.T., S.M. Datra dan G. Foster. 2008. Akuntansi Biaya: dengan Penekanan Manajerial. Erlangga. Jakarta.

Ikatan Akuntansi Indonesia. 2014. Pernyataan Standar Akuntansi Keuangan Nomor 23 tentang Pendapatan. Ikatan Akuntansi Indonesia. Jakarta.

Kaparang, L., G.A.J. Rumagit, R.M. Kumaat, dan E.G. Tangkere. 2014. Analisis Keuntungan Industri Kecil Roti Allen di Kelurahan Tinoor Satu Kecamatan Tomohon Utara. Cocos. 5(4).

Kasmir. 2013. Analisis Laporan Keuangan. Edisi 1. Cetakan Keenam. RajaGrafindo Persada. Jakarta. 
Mulyadi. 2012. Akuntansi Biaya. Edisi Kelima. STIM YKPN. Yogyakarta.

Simamora, H. 2006. Akuntansi Manajemen. Salemba Empat. Jakarta.

Sukirno, S. 2008. Mikroekonomi: Teori Pengantar. Edisi Ketiga. RajaGrafindo Persada. Jakarta.

Suparyanto. 2014. Konsep Dasar Pendapatan Keluarga. http://dr-suparyanto.blogspot.com/ 2014/03/konsep-dasar-pendapatan-keluarga.html. 17 Desember 2018 (15:41).

Suwardjono. 2008. Teori Akuntansi Perekayasaan Pelaporan Keuangan. BPFE. Yogyakarta. 